\title{
GORDONIA POLYISOPRENIVORANS FROM GROUNDWATER CONTAMINATED WITH LANDFILL LEACHATE IN A SUBTROPICAL AREA: CHARACTERIZATION OF THE ISOLATE AND EXOPOLYSACCHARIDE PRODUCTION
}

\author{
Roberta Fusconi $^{1 \text { *; }}$ Mirna Januária Leal Godinhoํㅜ ${ }^{1}$ Isara Lourdes Cruz Hernández ${ }^{1}$; Nelma Regina Segnini Bossolan ${ }^{2}$ \\ ${ }^{1}$ Departamento de Ecologia e Biologia Evolutiva, Universidade Federal de São Carlos, São Carlos, SP, Brasil; ${ }^{2}$ Instituto de \\ Física, Universidade de São Paulo, São Carlos, SP, Brasil
}

Submitted: April 30, 2004; Returned to authors for corrections: June 01, 2005; Approved: February 26, 2006

\begin{abstract}
A strain of Gordonia sp. (strain Lc), from landfill leachate-contaminated groundwater was characterized by polyphasic taxonomy and studied for exopolysaccharide (EPS) production. The cells were Gram-positive, catalase-positive, oxidase-negative and non-motile. The organism grew both aerobically and, in anoxic environment, in the presence of $\mathrm{NaNO}_{3}$. Rods occured singly, in pairs or in a typical coryneform $\mathrm{V}$-shaped. The organism had morphological, physiological and chemical properties consistent with its assignment to the genus Gordonia and mycolic and fatty acid pattern that corresponded to those of $G$. polyisoprenivorans DSM $44302^{\mathrm{T}}$. The comparison of the sequence of the first 500 bases of the 16S rDNA of strain Lc gave $100 \%$ similarity with the type strain of Gordonia polyisoprenivorans DSM $44302^{\mathrm{T}}$. Experiments conducted in anaerobic conditions in liquid E medium with either glucose or sucrose as the main carbon source showed that sucrose did not support the growth of Lc strain and that on glucose the maximum specific growth rate was $0.17 \mathrm{~h}^{-1}$, representing a generation time of approximately 4 hours. On glucose, a maximum of total EPS was produced during the exponential phase $\left(126.17 \pm 15.63 \mathrm{~g} \mathrm{l}^{-1}\right)$. The production of free EPS exceeded that of capsular and the free/capsular EPS ratio increased from 1.9 during the exponential phase to 7.8 during the stationary phase. At present, six strains of G. polyisoprenivorans have been isolated from various environments. Lc is the sixth strain of G. polyisoprenivorans described, the second strain detected in the landfill leachatecontaminated groundwater and the first that is being studied for EPS production.
\end{abstract}

Key words: Gordonia polyisoprenivorans, exopolysaccharide, groundwater, landfill

\section{INTRODUCTION}

Exopolysaccharides (EPS)-producing microorganisms are emerging as a new and industrial important source of polymeric materials. An attempt has been made to isolate, identify and characterize abundant EPS-producing bacteria as an alternative approach to the potential use of genetically modified microorganisms for the production of novel and unique EPS suited for specific purposes (31).

Several bacterial strains produce EPS that can be referred to as capsular polysaccharide, when attached to the cell wall as a capsule, or as slime EPS or free EPS when produced as loose unattached material (40). EPS are of great ecological importance with respect to bacterial growth and survival strategies in different environments (10). In natural porous media, such as soil and aquifers, indigenous EPS-producing bacteria are capable of hindering the flow of water, reducing the volume of pores available for fluid transport and thus lowering the hydraulic conductivity $(4,41)$. In this way they can be used to prevent contamination of groundwater, using a technique named biological barrier, biobarrier or waste containment barrier $(11,34)$. Biobariers, formed by bacteria and the EPS they secret, clog the aquifer and physically separate adjacent areas of an underground region, preventing the propagation of a

*Corresponding Author. Mailing address: R. João Severiano Rodrigues da Cunha, 1000, casa 6, Jardim Indaiá. 38411-178, Uberlândia, MG, Brasil. Tel.: (+5516) 260-8323, Fax: (+5516) 260-8322. E-mail: rfusconi@gmail.com 
contaminating plume in the environment (4). Aquifer bioclogging can be achieved through the stimulation of indigenous microbes, by injecting a nutrient solution (34), or by injecting microbes along with the nutrient solution $(11,41)$. Optimization of EPS production by microorganisms is studied by culturing the latter under various conditions of $\mathrm{pH}$, temperature, oxygen, $\mathrm{C} / \mathrm{N}$ ratio and on different substrates (40).

The present investigation started out from the need to remedy the negative effects of the old landfill site in São Carlos (São Paulo State, Brazil) on adjacent groundwater. The localization of the landfill site is of great concern as it is located in the recharge area for the Guarani Aquifer (13). Considering the potential uses of EPS-producing strains in bioremediation technologies, the aim of this work was to report the characterization by polyphasic approach of an EPS-producing actinomycete strain isolated from groundwater underneath the old landfill site and to analyse the EPS production by the strain in a standard medium.

\section{MATERIALS AND METHODS}

\section{Bacterial strain}

During a screening for EPS-producing bacteria, strain Lc was isolated from the groundwater beneath the old municipal landfill of São Carlos City (upstate São Paulo, Brazil) (14). The strain was deposited at the Tropical Culture Collection (Fundação Tropical de Pesquisas e Tecnologia "André Tosello", Campinas, Brazil) under accession number CCT 7277.

\section{Characterization of the isolate}

Cell morphology was examined in 24 and 48-h-old cultures on nutrient broth, at $25^{\circ} \mathrm{C}$ in aerobic conditions, by scanning electron microscopy. Samples preparation was based on the procedures described in Bratbak (7) and Araújo (1). Samples were removed from liquid cultures and fixed with $2.5 \%$ glutaraldehyde in $0.1 \mathrm{M}$ phosphate buffer (PBS; pH 7.3) and washed three times trough $0.22 \mu \mathrm{m}$ polycarbonate membranes. The washed membranes were dehydrated in graded ethanol $(50 \%, 70 \%, 80 \%, 90 \%, 95 \%, 100 \%)$, mounted on aluminum specimen stubs and subjected to drying at $36^{\circ} \mathrm{C}$. After drying, the samples were sputter-coated (Sputter Coater, Balzers SCD 050 ) with approximately $20 \mathrm{~nm}$ of gold and analyzed with a digital scanning electron microscope (Digital Scanning Microscope DSM 960, Zeiss). The images were analyzed by the software Image-Pro Plus 4.0 (Media Cybernetics). Routine microbiological tests, including those for Gram stain reaction, oxygen requirements, oxidase, catalase, cell motility, and spore formation, were performed according to standard methods (36). The appearence and colour of colonies were noted after 3 and 7 days on nutrient agar at $25^{\circ} \mathrm{C}$. Carbon source utilization was performed in standard microtitration plates (F-form:Greiner) as described by Linos et al. (27). Amino acid analysis of wholecell hydrolysates followed the procedures described by Stanek and Roberts (39). The fatty acids methyl esters were prepared from 40-80 mg wet cells and analyzed as previously described $(19,32,35)$ and trimethylsilylated devivatives of mycolic acids according to Klatte et al. (23). Genomic DNA extraction and PCR amplification was performed as described by Rainey et al. (33). The partial sequence of the $16 \mathrm{~S}$ rDNA of strain Lc was aligned manually with published sequences from representatives of actinomycetes obtained from EMBL.

\section{Growth experiments}

For growth experiments, stock cultures, kept on nutrient agar at $4^{\circ} \mathrm{C}$, were plated on nutrient agar at $25^{\circ} \mathrm{C}$ and resuspended in $10 \mathrm{~mL}$ nutrient broth. This suspension was used to prepare a preculture under aerobic conditions in nutrient medium, to the late of the $\log$ phase of growth $(26 \mathrm{~h})$. The inoculum $(40 \mathrm{~mL})$, standardized at O.D. ${ }_{600} 0.3$, was removed from the preculture and transferred to $1000 \mathrm{~mL}$ flasks containing $760 \mathrm{~mL}$ of E medium (9) with either $10 \%(\mathrm{w} / \mathrm{v})$ sucrose or $10 \%(\mathrm{w} / \mathrm{v})$ glucose solutions as carbon sources and incubated under anaerobic conditions in the presence of $\mathrm{NaNO}_{3}\left(1 \mathrm{~g} \mathrm{l}^{-1}\right)$ at $25^{\circ} \mathrm{C}$, in an attempt to simulate in situ conditions. Before sterilization, the atmosphere of the media was replaced with nitrogen gas. All experiments were undertaken in triplicate and agitation was maintained at $100 \mathrm{rev} \mathrm{min}^{-1}$.

Cell growth was periodically monitored by measuring optical density (O.D.600) and by direct counts of cell number by phase contrast microscopy in samples from the end of the exponential phase of growth and from the stationary phase of growth $(24 \mathrm{~h}$ after the first sample). The maximum specific growth rate $\left(\mu_{\max }\right)$ was determined by linear regression (indicated by the correlation coefficient $\mathrm{r}^{2}$ ) from plots of O.D.600 $\left(\operatorname{lnCX} / \mathrm{CX}_{0}\right) v s$. time, where $\mathrm{CX}_{0}$ is initial O.D. 600 value and CX is O.D. 600 value at each time point. The generation time was calculate as $\mathrm{Tg}=\mathrm{Ln} 2 / \mu_{\max }$. To verify the existence of the exponential phase, a minimum of four consecutive points were used (5). The reproducibility of triplicates was evaluated by Kruskal Wallis test (nonparametric ANOVA). Significant differences were determined at $\mathrm{p}<0.05$.

\section{EPS quantification}

For EPS quantification, samples from the end of the exponential phase and from the stationary phase, from experiments in E medium with either glucose and sucrose, were filtered through $0.45 \mu \mathrm{m}$ filter to remove the cells and dialyzed (cellulose dialysis tube, molecular weight cut-off 12000 to 16000) against distilled water for $48 \mathrm{~h}$ (water was changed three times each day) to eliminate residual sugars from the culture medium. Total carbohydrates was measured by the phenol-sulfuric acid method (12) in order to estimate the amounts of total, free and capsular EPS produced. To determine the total EPS, samples were heated for 60 minutes in a boiling water bath to free and dissolve capsular EPS. Both total and free EPS were quantified directly by the phenol-sulfuric acid method and capsular EPS was determined by subtracting the free EPS concentration from 
the total (15). The values shown for EPS were calculated by subtracting the amount of background interference in fresh media from that detected in cultures broth $(3,22)$. The amount of EPS was expressed as $\mathrm{g}^{-1}$ using glucose as standard.

\section{RESULTS}

\section{Characterization of the isolate}

In 24-h-old cultures, dimensions of cells were $2.15 \pm 0.54 \mathrm{x}$ $0.57 \pm 0.05 \mu \mathrm{m}$ and, in 48 -h-old cultures, $1.16 \pm 0.22 \times 0.61 \pm 0.05 \mu \mathrm{m}$ (Fig. 1). Cells occurred singly, in pairs, in clusters or in a typical coryneform V-shape. The cells of strain Lc were Gram-positive, catalase-positive, oxidase-negative, non-motile and no spores could be detected. They also grew both aerobically and in anoxic environment in the presence of $\mathrm{NaNO}_{3}$. The colonies were beige and included both smooth and rough variants upon cultivation

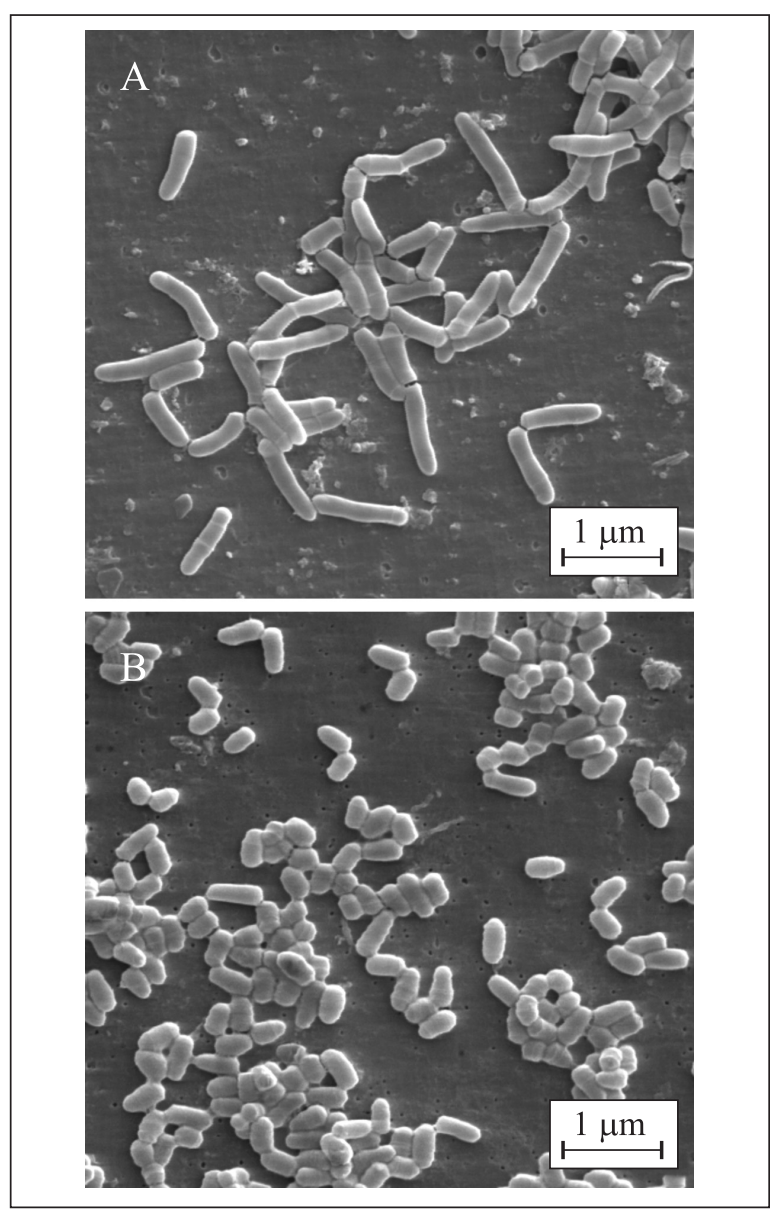

Figure 1. Scanning electron micrograph of strain Lc in nutrient broth: (A) 24-h-old culture; (B) 48-h-old culture. Incubation was carried out under aerobic conditions at $25^{\circ} \mathrm{C}$ and with agitation (100 rev min $\left.^{-1}\right)$. on nutrient agar. After exposure to light, the colonies changed to light pink after three days and to pastel orange after seven days. The results of the biochemical tests revealed that strain Lc was able to utilize thirteen of the thirty-two carbon sources tested and, of the compounds tested for hydrolysis by the strain, only $p$-nitrophenyl- $\beta$-D-xyloside gave a positive reaction (Table 1 ). This utilization pattern was most similar to Gordonia polyisoprenivorans DSM $44302^{\mathrm{T}}$ (Sorensen's similarity coefficient $=0.75$ and $r^{2}=0.83$ ). Although some differences were found in the tests: (a) strain Lc did not utilize D-glucosaminic acid, D-turanose, caprate, citrate, L-alanine, L-aspartate, L-proline or quinate; (b) strain Lc hydrolyzed $p$-nitrophenyl- $\beta$-D-xyloside; (c) whereas G. polyisoprenivorans DSM $44302^{\mathrm{T}}$ has a variable reaction to tyramine as $\mathrm{C}$-source, strain Lc utilized this source; (d) strain Lc did not utilize caprate or 4-aminobutyrate, carbon sources not determined for G. polyisoprenivorans DSM $44302^{\mathrm{T}}$.

Whole cell hydrolysates contained meso-diaminopimelic acid as the only diamino acid of the peptidoglycan. Strain Lc synthesized a homologous series of mycolic acids ranging from $\mathrm{C}_{57}$ to $\mathrm{C}_{64}$, with $\mathrm{C}_{60}$ and $\mathrm{C}_{62}$ being the principal mycolic acids. The fatty acid profile consisted of unbranched, saturated and unsaturated fatty acids plus tuberculostearic acid (TBSA) and the main fatty acids were $\mathrm{C}_{16: 0}$ (palmitic acid), cis- $9 \mathrm{C}_{18: 1}$ (oleic acid) and TBSA. A partial sequence of $16 \mathrm{~S}$ rDNA from the strain was determined and the first 500 bases of the 16S rDNA of strain Lc had a sequence similarity of $100 \%$ to the type strain of G. polyisoprenivorans DSM $44302^{\mathrm{T}}$.

\section{Growth and EPS production experiments}

Fig. 2 shows growth of Lc strain in E medium with glucose in anaerobic conditions. D.O. 600 values are the mean of three experiments (no significant differences between triplicates. $p$ > 0.05). Sucrose did not support the growth of Lc strain, while in E medium with glucose, the stationary phase was reached between 26 and $28 \mathrm{~h}$ of incubation and the $\mu_{\max }$ was calculated to be $0.17 \mathrm{~h}^{-1}\left(\mathrm{r}^{2}=0.985\right)$, representing a generation time of approximately 4 hours. Optical density went from $0.016 \pm 0.003$ $(0 \mathrm{~h})$ to $0.807 \pm 0.005(28 \mathrm{~h})$ and cell density rose from $7.9 \times 10^{6}$ bact $\mathrm{mL}^{-1}(0 \mathrm{~h})$ to $1.6 \times 10^{9} \pm 0.34$ bact $\mathrm{mL}^{-1}(28 \mathrm{~h})$, a 202.5 -fold increase overall. After $52 \mathrm{~h}$ of incubation the cell number was

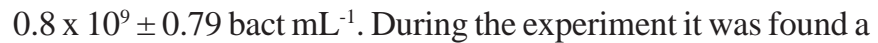
medium acidification, in which the $\mathrm{pH}$ decreased from $6.7 \pm 0.09$ (0h) to $6.07 \pm 0.06$ at the end of the growth curve $(52 \mathrm{~h})$. In E medium with glucose (Fig. 2), total EPS production by Lc strain during the exponential phase was $126.17 \pm 15.63 \mathrm{~g} \mathrm{~L}^{-1}$. Lc strain produced larger amounts of free EPS $\left(81.97 \pm 14.14 \mathrm{~g} \mathrm{~L}^{-1}\right)$ than capsular EPS $\left(44.20 \pm 3.80 \mathrm{~g} \mathrm{~L}^{-1}\right)$. After $52 \mathrm{~h}$, during the stationary phase, the amount of total EPS decreased to $123.97 \pm 4.28 \mathrm{~g} \mathrm{~L}^{-1}$ but the free/capsular EPS ratio increased from 1.9 during the exponential phase to 7.8 during the stationary phase when the amount of free EPS produced increased to $109.80 \pm 16.34 \mathrm{~g} \mathrm{~L}^{-1}$ and that of capsular EPS decreased to $14.17 \pm 12.12 \mathrm{~g} \mathrm{~L}^{-1}$. 
Table 1. Physiological properties of strain Lc and type strains of the genus Gordonia (27). Strains: 1, G. aichiensis DSM 43978 ${ }^{\mathrm{T}} ; 2$, G. alkanivorans DSM 44369 ${ }^{\mathrm{T}} ; 3$, G. amarae DSM 43392 $;$; , G. amicalis DSM 44461 ${ }^{\mathrm{T}} ; 5$, G. bronchialis DSM 43247 $;$;, G. desulfuricans

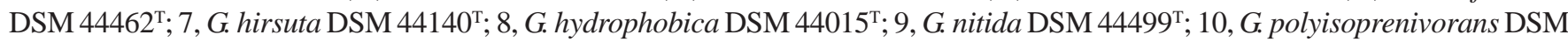

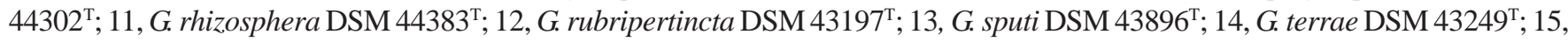
G. westfalica DSM 44215 ; 16 , strain Lc. CXY, p-nitrophenyl- $\beta$-D-xyloside; CCH, p-nitrophenylphosphoryl choline; CDP, 2desoxythymidine-5-p-nitophenyl; nd, not determined; v, variable.

\begin{tabular}{|c|c|c|c|c|c|c|c|c|c|c|c|c|c|c|c|c|}
\hline Characteristic & 1 & 2 & 3 & 4 & 5 & 6 & 7 & 8 & 9 & 10 & 11 & 12 & 13 & 14 & 15 & 16 \\
\hline \multicolumn{17}{|l|}{ Utilization of: } \\
\hline $\mathrm{N}$-acetyl-D-glucosamine & - & + & - & - & + & + & - & - & - & + & + & - & - & - & - & + \\
\hline D - Galactose & + & + & + & + & + & + & + & + & + & + & + & - & + & + & + & + \\
\hline Glucarate & - & + & - & + & - & - & - & + & + & - & - & + & - & + & - & - \\
\hline Gluconate & - & + & - & + & + & + & - & - & + & + & + & + & - & - & - & + \\
\hline D-Glucosaminic acid & - & + & - & + & - & + & - & - & + & + & + & + & - & - & + & - \\
\hline L-Rhamnose & - & - & - & + & + & - & - & - & + & + & + & + & - & + & - & + \\
\hline D-Ribose & - & + & + & + & - & + & - & - & + & - & - & + & - & - & + & - \\
\hline D-Sucrose & - & + & + & + & + & + & - & + & + & + & + & + & - & + & + & + \\
\hline D-Turanose & - & + & + & + & + & + & - & + & + & + & + & - & - & - & - & - \\
\hline Caprate & + & + & nd & + & + & + & nd & nd & - & nd & - & $\mathrm{v}$ & + & - & + & - \\
\hline D-Arabitol & - & + & + & - & - & - & - & - & - & + & - & + & + & + & + & + \\
\hline i-Inositol & - & + & - & - & + & - & + & - & + & + & + & - & - & - & - & + \\
\hline Citrate & + & + & + & + & - & + & - & + & + & + & + & - & + & + & + & - \\
\hline 2-Hydroxyvalerate & - & + & - & + & - & + & + & - & + & - & - & - & - & - & - & - \\
\hline 2-Oxoglutarate & + & + & + & + & - & + & + & - & + & - & + & - & + & + & + & - \\
\hline Pimelate & - & + & - & + & - & + & - & - & - & - & - & - & - & - & - & - \\
\hline Succinate & - & + & - & + & + & - & - & + & + & - & + & - & + & - & - & - \\
\hline L-Alanine & + & + & - & + & + & + & - & - & + & + & - & + & - & - & - & - \\
\hline 4-Hydroxybenzoate & - & + & + & + & + & + & - & - & + & + & + & - & - & - & - & + \\
\hline L-Aspartate & + & + & - & + & - & - & - & - & + & + & - & - & - & - & + & - \\
\hline L-Leucine & - & + & - & + & + & + & - & + & - & - & - & - & - & - & - & - \\
\hline L-Proline & - & + & + & - & - & + & - & + & - & + & - & - & - & - & - & - \\
\hline L-Serine & - & - & - & + & - & - & - & - & + & - & - & - & - & - & - & - \\
\hline L-Valine & - & - & + & - & + & - & - & + & + & + & - & - & - & - & - & + \\
\hline Putrescine & - & + & + & + & - & + & - & - & - & + & - & - & - & - & - & + \\
\hline Tyroamine & - & + & nd & + & - & + & nd & nd & + & $\mathrm{v}$ & + & - & - & - & - & + \\
\hline Acetamide & - & - & - & + & + & + & - & + & - & + & - & - & - & - & - & + \\
\hline Benzoate & - & + & - & - & - & - & - & - & + & + & + & + & - & + & + & + \\
\hline 3-Hydroxybenzoate & - & + & - & - & - & + & - & - & + & - & + & - & - & - & - & - \\
\hline 4-Aminobutyrate & + & - & nd & - & - & + & nd & nd & - & nd & - & - & - & - & - & - \\
\hline Phenylacetate & - & + & - & + & + & + & - & - & + & - & - & + & - & - & - & - \\
\hline Quinate & + & - & + & - & - & - & - & - & - & + & + & - & - & - & - & - \\
\hline \multicolumn{17}{|l|}{ Hydrolysis of: } \\
\hline CXY & - & - & - & - & - & - & - & - & - & - & - & - & - & + & - & + \\
\hline $\mathrm{CCH}$ & - & + & - & + & - & + & + & + & + & - & - & - & - & - & - & - \\
\hline CDP & - & - & - & - & - & + & - & + & - & - & - & - & - & - & - & - \\
\hline
\end{tabular}

\section{DISCUSSION}

In any attempt to resolve problems of environmental contamination with the aid of microorganisms, it is essential to isolate, select and study the metabolic potential of strains living in the affected site. Strain Lc had morphological, physiological and chemical properties consistent with its assignment to the genus Gordonia (37), mycolic and fatty acid pattern that corresponded to those of G. polyisoprenivorans DSM $44302^{\mathrm{T}}$ and $100 \%$ sequence similarity of the first 500 bases of the $16 \mathrm{~S}$ 


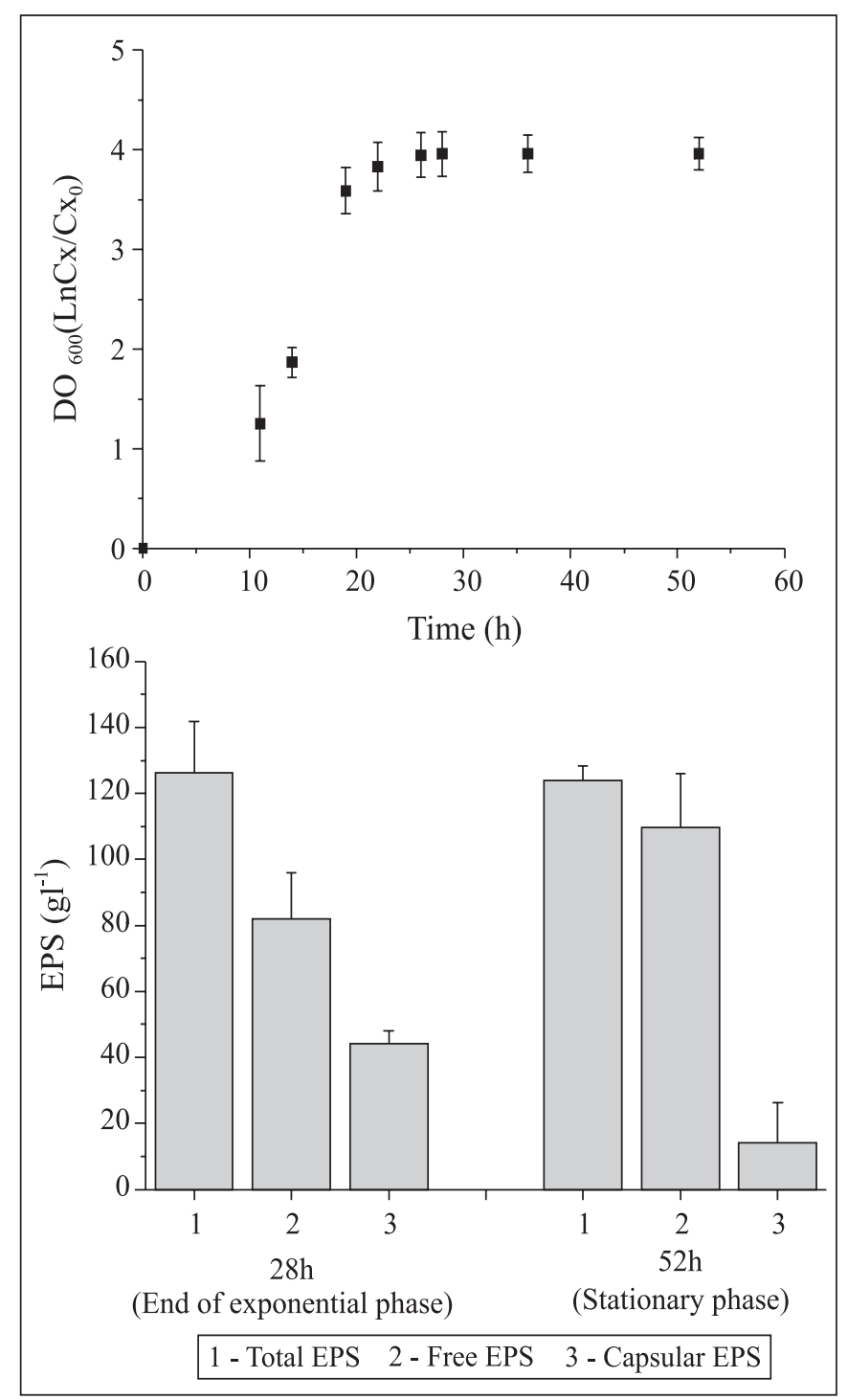

Figure 2. Cultivation of Lc strain in E medium with glucose. (A) Growth at indicated time point; (B) EPS production at indicated time point. Incubation was carried out under anaerobic conditions at $25^{\circ} \mathrm{C}$ and with agitation $\left(100 \mathrm{rev} \mathrm{min}^{-1}\right)$. The values are the mean of three experiments. $\mathrm{Bar}=$ standard deviation.

rDNA with the type strain of Gordonia polyisoprenivorans DSM 44302 ${ }^{\mathrm{T}}$ (27).

According to the proposed hierarchic classification system for the actinomycete, the genus Gordonia is currently assigned to the class Actinobacteria, order Actinomycetales, suborder Corynebacterineae, family Gordoniaceae (38). Like other members of genus Gordonia (37), strain Lc was Gram-positive, catalase-positive, oxidase-negative, non-motile and non- sporing. Whole cell hydrolysates contained mesodiaminopimelic acid as the only diamino acid of the peptoglican, mycolic acids ranging between C48 and C66 and unbranched, saturated and unsaturated fatty acids plus TBSA. In recent decades there has been a great deal of interest in the identification of bacteria of the genus Gordonia, partly due to their important role in the biodegradation of environmental pollutants like benzothiophenes (21), alkylpyridines (44), hexadecane (25), ethyl $t$-butyl ether, methyl $t$-butyl ether and $t$-amyl methyl ether (17), nitrile compounds (6), rubber substrates $(27,30)$ and hydrocarbons like paraffin (43).

Up to now, six strains of G. polyisoprenivorans have been isolated from various environments in various geographic regions of the world. Three strains have confirmed rubberdegrading properties: strain VH2 (DSM 44266) from the soil of a Hevea brasiliensis plantation in Vietnam, strain Kd2 (DSM 44302) from foul water inside a deteriorated car tyre in Germany (26) and strain Y2K from a mixed culture formerly considered to be an axenic culture of a rubber-decomposing Pseudomonas aeruginosa strain (2) isolated from foul water inside a deteriorated car tyre in Germany (29). The forth strain was isolated from a clinical specimen (blood sample taken from a aptient'sHickman catheter) (20). The fifth strain ( $G$. polyisoprenivorans CCT 7137), was isolated from subtropical landfill-leachete contaminatel groundwater in Brazil (14) and the sixth, which is the strain described in the present work (strain Lc), was isolated from the same groundwater, during a screening for EPS-producing bacteria (14). Lc is the second strain of G. polyisoprenivorans detected in groundwater adjacent to the old municipal landfill of the city of São Carlos and the first that is being studied for EPS production.

In contrast to the first strain isolated from this source, $G$. polyisoprenivorans CCT 7137 (15), which produced only smooth colonies, strain Lc produced some rough variants. The ability of strains of $G$. polyisoprenivorans to produce smooth and rough variants was previously noted in strains VH2 $(2,23)$ and Y2K (2). Fusconi and Godinho (14) selected this strain for EPS production studies on the basis of the mucoid aspect of colonies on solid media and the mucoid mode of growth in liquid media, characteristics that indicate production of large amounts of EPS by bacterial strains $(8,18)$. Experimental measurement of EPS produced by Lc strain during growth on one out of the two carbon sources confirmed predictions of EPS production by the strain.

Lc strain produced a larger quantity of free EPS than of capsular EPS during its growth in E medium with glucose, a characteristic of fundamental importance in terms of the bioclogging of porous media and for in situ bioremediation through biobarrier technology. In a study on the effect of bacterial EPS on the hydraulic conductivity of porous media, Vandevivere and Baveye (41) reported that EPS in the free form exerted a much stronger influence than capsular EPS. 
The maximum specific growth rate of Lc strain in E medium with glucose in anaerobic conditions $\left(\mu_{\max }=0.17 \mathrm{~h}^{-1}\right)$ was similar to those measured for G. polyisoprenivorans CCT 7137 in GYM $\left(\mu_{\max }=0.175 \mathrm{~h}^{-1}\right)$ and in sugarcane molasses $2 \%\left(\mu_{\max }=0.157 \mathrm{~h}^{-1}\right)$ and $3 \%\left(\mu_{\max }=0.168 \mathrm{~h}^{-1}\right)$, in aerobic conditions $(15)$. The ability to grow and produce EPS in anaerobic conditions in the laboratory is a fundamental requirement if an organism is to produce the metabolite in situ, or even for low-cost production at laboratory scale. Wachenheim and Patterson (42) emphasized the potential of anaerobic culture for EPS production by bacteria and showed that anaerobic species can be used for EPS production on the industrial scale, offering reduced culture costs and a lower probability of contamination during the fermentation process. However, the authors pointed out the need for basic and applied research to determine the economic viability of the culture and EPS production (cost/benefit ratio) of a particular strain.

The production of polymers and the consequent formation of biofilm by G. polyisoprenivorans was observed by Linos et al. (28) during biodegradation experiments of natural and synthetic (cis-1,4-polyisoprene) rubbers, while the production of an acidic polysaccharide (gordonan) with cell aggregationinducing activity in insect BM-N4 cells by another Gordonia sp., was reported by Kondo et al. (24). In spite of those investigations, in our knowledge, there have been no attempts to optimize production of EPS of G. polyisoprenivorans.

At least four characteristics of Lc strain suggest its potential value: a) it is a G. polyisoprenivorans strain; b) it is an EPSproducing strain; c) production of free EPS exceeded that of capsular; d) EPS was produced under anaerobiosis. The organism described here represents the fifth strain of $G$. polyisoprenivorans cited in the literature, the second isolated from the groundwater adjacent to the old municipal landfill formerly used by the city of São Carlos (São Paulo State, Brazil) and the first that is being studied for EPS production.

Given the potential of the family Gordoniaceae and of EPSproducing bacteria for biotechnological exploitation, both in bioremediation of enviromental pollutants and in the synthesis of chemicals, we recommend that the EPS-producing strain Lc is studied further, with a view to its possible utilization for in situ bioremediation of the degraded area from which Lc strain was isolated.

\section{ACKNOWLEDGEMENTS}

We would like to thank Capes (Coordenação de Aperfeiçoamento de Pessoal de Nível Superior, Brazil) and PPGERN (Programa de Pós-Graduação em Ecologia e Recursos Naturais, UFSCar, Brazil) for financial support and Dr. R.M. Kroppenstedt (DSMZ, Germany), Dr. E.P. Gianotti (USP, Brazil) and Dr. A.C. Peret (UFSCar, Brazil) for technical assistance during this study.

\section{RESUMO}

\section{Gordonia polyisoprenivorans de águas subterrâneas contaminadas por chorume, em região subtropical: caracterização da linhagem e produção de exopolissacarídeos}

Uma linahgem de Gordonia sp. (linhagem Lc), proveniente de águas subterrâneas contaminadas por chorume, foi caracterizada por taxonomia polifásica e estudada quanto à produção de exopolissacarídeos (EPS). As células, bastonetes agregados, isolados ou aos pares em formato de $\mathrm{V}$, típico de bactérias corineformes, apresentaram reação Gram positiva, catalase positiva, oxidase negativa, não apresentaram motilidade. $\mathrm{O}$ organismo cresceu em aerobiose e em ambiente anóxico na presença de $\mathrm{NaNO}_{3}$. A linhagem apresentou características morfológicas, bioquímicas e propriedades quimiotaxônomicas típicas do gênero Gordonia e perfil de ácidos micólicos e ácidos graxos correspondentes aos de G. polyisoprenivorans DSM $44302^{\mathrm{T}}$. A análise do seqüenciamento dos primeiros 500 pares de bases do rDNA16S da linhagem mostrou 100\% de similaridade com Gordonia polyisoprenivorans DSM44302 ${ }^{\mathrm{T}}$ Experimentos conduzidos em condições anaeróbias em meio E com sacarose ou glicose como principal fonte de carbono, mostraram que a linhagem não cresceu quando cultivada com sacarose. Entretanto, utilizando-se glicose, a velocidade específica máxima de crescimento foi $0,17 \mathrm{~h}^{-1}$, o tempo de geração de aproximadamente 4 horas e o máximo de produção de EPS total ocorreu durante a fase exponencial $\left(126,17 \pm 15,63 \mathrm{gl}^{-1}\right)$. A produção de EPS livre excedeu à de capsular e a relação EPS livre/EPS capsular aumentou de 1,9, durante a fase exponencial para 7,8 durante a fase estacionária. Até então, foram isoladas seis linhagens de G. polyisoprenivorans de diferentes ambientes. A linhagem Lcé a sexta linhagem de G. polyisoprenivorans descrita, a segunda detectada nas águas subterrâneas em questão e a primeira cuja produção de EPS está sendo estudada.

Palavras-chave: Gordonia polyisoprenivorans, exopolissacarídeos, águas subterrâneas, aterro controlado.

\section{REFERENCES}

1. Araújo J.C. Caracterização e evolução de biofilme em reator anaeróbio de leito fluidificado alimentado $\mathrm{cm}$ esgoto sanitário sintético. São Carlos, 1995. 158p. (Master Science. Hidráulica e Saneamento. USP).

2. Arenskötter, M.; Baumeister, D.; Berekaa, M.M.; Pötter, G.; Kroppenstedt, R.M.; Linos, A.; Steinbüchel, A. Taxonomic characterization of two rubber degrading bacteria belonging to the species Gordonia polyisoprenivorans and analysis of hyper variable regions of $16 \mathrm{~S}$ rDNA sequences. FEMS Microbiol. Lett., 205, 277-282, 2001.

3. Bergmaier, D.; Champagne, C.P.; Lacroix, C. Exopolysaccharide production during batch cultures with free and immobilized Lactobacillous rhamnosus RW-9595M. J. Appl. Microbiol., 95, 10491057, 2003.

4. Bleikinsopp, S.A.; Costerton, J.W. Understanding bacterial biofilms Trends in Biotechnology, 9, 138-143, 1991. 
5. Borzani, W. Objective criteria to confirm the existence of the exponential growth phase in a batch microbial process. Rev. Microbiol., 24, 278-280, 1993.

6. Brandão, P.F.B.; Maldonado, L.A.; Ward, A.C.; Bull, A.T.; Goodfellow, M. Gordonia namibiensis sp. nov., a novel nitrile metabolizing actinomycete recovered from an African sand. Syst. Appl. Microbiol., 24, 510-515, 2001.

7. Bratbak, G. Microscope methods for measuring bacterial biovolume: epifluorescence microscopy, scanning electron microscopy, and transmission electron microscopy. In: Kemp, P.F.; Sherr, B.F.; Sherr, E.B.; Cole, J.J. (eds.) Handbook of Methods in Aquatic Microbial Ecology. Lewis Publishers, Boca Raton, 1993, p.309-317.

8. Chan, R.; Lam, J.S.; Costerton, J.W. Influence of culture conditions on expression of the mucoid mode of growth of Pseudomonas aeruginosa. J. Clin. Microbiol., 19, 8-16, 1984.

9. Clark, J.B.; Munnecke, D.M.; Jenneman, G.E. In situ microbial enhancement of oil recovery. Dev. Ind. Microbiol., 22, 695-701, 1981.

10. Costerton, J.W. The role of bacterial exopolysaccharides in nature and disease. J. Ind. Microbiol. Biotechnol., 22, 551-563, 1999.

11. Dennis, M.L.; Turner, J.P. Hydraulic conductivity of compacted soil treated with biofilm. J. Geotech. Geoenviron. Eng., 2, 120- 127, 1998.

12. Dubois, M.; Gilles, L.A.; Hamilton, J.K.; Reberes, P.A.; Smith, F. Colorimetric methods for determination of sugars and related substances. Anal. Chem., 28, 350-356, 1956.

13. Fusconi, R.; Godinho, M.J. Bacteria and protozoa population in groundwater in a landfill area in São Carlos, SP. Rev. Microbiol., 30, 196-202, 1999.

14. Fusconi, R.; Godinho, M.J. Screening for exopolysaccharideproducing bacteria from sub-tropical polluted groundwater. Braz. J. Biol., 62, 363-369; 2002.

15. Fusconi, R.; Godinho, M.J.L.; Bossolan, N.R.S. Characterization and culture on sugarcane molasses of Gordonia polyisoprenivorans CCT 7137, a new strain isolated from contaminated groundwater in Brazil. World J. Microbiol. Biotechnol., 2005, in press.

16. Hannemann, T.F. Effects of carbon source on bacterial exopolysaccharide production under denitrifying conditions. Washington, 1994, 149p. (Master Science. Department of Civil and Environmental Engineering. Washington State University).

17. Hernandez-Perez, G.; Fayolle, F.; Vandecasteele, J.P. Biodegradation of ethyl $t$-butyl ether (ETBE), methyl $t$-butyl ether (MTBE) and $t$ amyl methyl ether (TAME) by Gordonia terrae. Appl. Microbiol. Biotechnol., 55, 117-121, 2001.

18. Junkins, A.D.; Doyle, M.P. Demonstration of exopolysaccharide production by enterohemorrhagic Escherichia coli. Current Microbiol., 25, 9-17, 1992.

19. Kämpfer, P.; Kroppenstedt, R.M. Numerical analysis of fatty acid patterns of coryneform bacteria and related taxa. Can. J. Microbiol., 42, 989-1005, 1996

20. Kempf, V.A.J.; Schmalzing, M.; Yassin, A.F.; Schaal, K.P.; Baumeister, D.; Arenskötter, M.; Steinbüchel, A. Gordonia polyisoprenivorans septicemia in a bone marrow transplant patient. Eur. J. Clin. Microbiol. Infect. Dis., 23, 226-228, 2004.

21. Kim, S.B.; Brown, R.; Oldfield, C.; Gilbert, S.C.; Iliarionov, S.; Goodfellow, M. Gordonia amicalis sp. nov. a novel dibenzothiophenedesulphurizing actinomycete. Int. J. Syst. Evol. Microbiol., 50, 20312036. 2000

22. Kimmel, A.S.; Roberts, R.F. Development of a growth medium suitable for exopolysaccharide production by Lactobacillus delbrueckii ssp. Bulgaricus RR. Int. J. Food Microbiol., 40, 87-92, 1998.

23. Klatte, S.; Kroppenstedt, R.M.; Rainey, F.A. Rhodococcus opacus sp. nov., an unusual nutritionally versatile Rhodococcus-species. Syst. Appl. Microbiol., 17, 355-360, 1994.

24. Kondo, T.; Yamamoto, D.; Yokota, A.; Suzuki, A.; Nagasawa, H.; Sakuda, S. Gordonan, an acidic polysaccharide with cell aggregationinducing activity in insect BM-N4 cells, produced by Gordonia sp. Biosci. Biotechnol. Biochem., 64, 2388-2394, 2000.
25. Kummer, C.; Schumann, P.; Stackebrandt, E. Gordonia alkanivorans sp. nov., isolated from tar-contaminated soil. Int. J. Syst. Bacteriol., 49, 1513-1522, 1999.

26. Linos, A.; Steinbüchel, A. Microbial degradation of natural and synthetic rubbers by novel bacteria belonging to the genus Gordona. Kautsch. Gummi Kunstst., 51, 496-499, 1998.

27. Linos, A.; Steinbüchel, A.; Spröer, C.; Kroppenstedt, R.M. Gordonia polyisoprenivorans sp. nov., a rubber-degrading actinomycete isolated from an automobile tyre. Int. J. Syst. Bacteriol., 49, 1785-1791, 1999.

28. Linos, A.; Berekaa, M.M.; Reichelt, R.; Keller, U.; Schmitt, J.; Flemming, H.-C.; Kroppenstedt, R.M.; Steinbüchel, A. Biodegradation of cis-1,4-polyisoprene rubbers by distinct actinomycetes: microbial strategies and detailed surface analysis. Appl. Environ. Microbiol., 66, 1639-1645, 2000.

29. Linos, A.; Reichelt, R.; Keller, U.; Steinbüchel, A. A Gram-negative bacterium, identified as Pseudomonas aeruginosa AL98, is a potent degrader of natural rubber and synthetic cis-1,4-polyisoprene. FEMS Microb. Lett., 182, 155-161, 2000.

30. Linos, A.; Berekaa, M.M.; Steinbüchel, A.; Kim, K.K.; Spröer, C.; Kroppenstedt, R.M. Gordonia westfalica sp. nov., a novel rubberdegrading actinomycete. Int. J. Syst. Evol. Microbiol., 52, 11331139, 2002.

31. Muralidharan, J.; Jayachandran S. Physicochemical analyses of the exopolysaccharides produced by a marine biofouling bacterium, Vibrio alginolyticus. Process Biochem., 38, 841-847, 2003.

32. Miller, L.T. Single derivatization method for routine analysis of bacterial whole-cell fatty acid methyl esters, including hydroxy acids. J. Clin. Microbiol., 16, 584-586, 1982.

33. Rainey, F.A.; Ward-Rainey, N.; Kroppenstedt, R.M.; Stackebrandt, E. The genus Nocardiopsis represents a phylogenetically coherent taxon and a distinct actinomycete lineage: proposal of Nocardiopsaceae fam. nov. Int. J. Syst. Bacteriol., 46, 1088-1092, 1996.

34. Ross, N.; Villemur, R.; Deschênes. L.; Samson, E. Clogging a limestone fracture by stimulating groundwater microbes. Water Res., 35, 20292037, 2001

35. Sasser, M. Identification of bacteria by gas chromatography of cellular fatty acids. USFCC Newsl, 20, 1-6, 1990.

36. Smibert, R.M.; Krieg, N.R. Phenotypic characterization. In: Gerhardt, P.; Murray, R.G.E.; Wood, W.A.; Krieg, N.R. (eds.) Methods for general and molecular bacteriology. American Society for Microbiology Press, Washington, 1994, p.607-654.

37. Stakebrandt, E.; Smida, J.; Collins, M.D. Evidence of phylogenetic heterogeneity within the Genus Rhodococcus: revival of the genus Gordona (Tsukamura). J. Gen. Appl. Microbiol., 34, 341-348, 1988.

38. Stackebrandt, E.; Rainey, F.A.; Ward-Rainey, N.L. Proposal for a new hierarchic classification system. Actinobacteria classis nov. Int. J. Syst. Bacteriol., 47, 479-491, 1997.

39. Staneck, J.L.; Roberts, G.D. Simplified approach to identification of aerobic actinomycetes by thin-layer chromatography. Appl. Microbiol., 28, 226-231. 1974.

40. Sutherland, I.W. Biotechnology of microbial exopolysaccharides. Cambridge University Press, Cambridge, 1990, 163p.

41. Vandevivere, P.; Baveye, P. Effect of bacterial extracellular polymers on the saturated hydraulic conductivity of sand columns. Appl. Environ.Microbiol., 58, 1690-1698, 1992.

42. Wachenheim, D.E.; Patterson, J.A. Anaerobic production of extracellular polysaccharide by Butyrivibrio fibrisolvens nyx. Appl. Environ. Microbiol., 58, 385-91, 1992.

43. Xue, Y.; Sun, X.; Zhou, P.; Liu, R.; Liang, F.; Ma, Y. Gordonia paraffinivorans $s p$. nov., a hydrocarbon - degrading actinomycete isolated from an oil-producing well. Int. J. Syst. Evol. Microbiol., 53, 1643-1646, 2003.

44. Yoon, J.-H.; Lee, J.J.; Kang, S.-S.; Takeuchi, M.; Shin, Y.K.; Lee, S.T.; Kang, K.H.; Park Y.-H. Gordonia nitida sp. nov., a bacterium that degrades 3-ethylpyridine and 3-methlpyridine. Int. J. Syst. Evol. Microbiol., 50, 1203-1210, 2000. 